\title{
COMPARATIVE STUDY BETWEEN THINK ALOUD AND VISUAL IMAGERY IN ENHANCING STUDENTS' READING COMPREHENSION
}

\author{
Sylvania Walanda Siagian, Caroline Victorine Katemba \\ English Education Dept. \\ Universitas Advent Indonesia \\ Email: sylvaniasiagian@gmail.com
}

\begin{abstract}
The purpose of this study is to find out whether Think Aloud and Visual Imagery have significant difference in enhancing students' reading comprehension. This study used comparative design, test the comprehension of the students through pre-test, treatment, and post-test. This research was done to 32 students of class $8 \mathrm{~F}$ in Visual Imagery group; they were given passage to read and draw the image created in her mind on the paper; and 29 students of class 8E in Think Aloud group; the teacher and students think aloud the answers to the questions that were found in the text. The study was done in SMPN 1 Parongpong, West Bandung for 5 weeks or 640 minutes. Result of the study showed the average gain for Visual Imagery group is 0.038 and Think Aloud group is 0.125 . The $\mathrm{p}$-value $=0.686>\alpha(0.05)$, which means $\mathrm{H}_{0}$ is not rejected. Thus, there is no significant difference on students' reading comprehension between those who are taught using Think-Aloud and those who are taught using Visual Imagery.
\end{abstract}

Keyword: Reading comprehension, Think Aloud, Visual Imagery

\section{INTRODUCTION}

Students in Indonesia have different reading comprehension ability especially in English. Some students go to schools with an international standards and are exposed to English daily. Some students go to public schools, have dozens of classmate, and learn English twice in a week. Then, some students in rural area go to small schools that lack facilities and teachers, have their teachers and limited text books as the only source of learning English. These things creates comprehension gap between the students, because as Pearson (1993, cited by Braunger \& Lewis, 2006) observes, "One is tempted to conclude that some of the best 'practice' for enhancing reading skill occurs when children are given greater opportunity to read everyday materials" (pp. 507-508). 
In addition, a research in Indonesia discovered that the students' skills in reading comprehension are quite far from satisfactory. It is said that from 15-year-old Indonesian students, sixty nine percent $(69 \%)$ of them have the worst reading performance internationally (Media Indonesia, 2003). Furthermore, Kompas, an Indonesian daily newspaper, (2003) reported that around $37.6 \%$ of 15 -year-old students are barely able to read the text without comprehending the meaning of the text. Only $24.8 \%$ out of them are capable to connect with the texts with their knowledge about. Thus, many students are still lacking in terms of comprehending a text (cited by Sukyadi \& Hasanah 2009). Therefore, as Indonesian students have already encountered problems with reading comprehension in Indonesian, the language that they've acquired and learned, they also find it way more difficult to read and comprehend reading in English, the foreign language that they do not acquire and learn it barely for a short time.

Riswanto, et al., (2014) stated that The International Association for the Evaluation of Educational Achievement showed the low reading score of Indonesian students among East Asia students. Indonesian students are only capable to comprehend $30 \%$ reading material, and to read commentary text that needs cognitive process is hard for them (IAE for the Evaluation of Educational Achievement, 2003). PISA (2009 cited by Riswanto, et al., 2014) database found out that Indonesian students' score is below the OECD average and is placed on the 57th of 65 countries.

According to Sunggingwati and Nguyen (2013) reading comprehension in a foreign language is far more complicated than reading in our first language. What makes it more complicated is that the school's environment hardly speak English, and only exposed to the language in the classroom at times when learning English. That may create lacks of proficiency in English when the students read English texts, then there will be greater difficulties in reading comprehension. Teachers' instruction is important to let the students take part in reading.

However, Bright (1973) stated that to provide direct experience of language used as part of real life in the way native learner gets his first language is quite impossible in any secondary school; one is defeated by the multiplicity of the context required: house, garden, sea-shore, food, farm, factory, death, marriage, divorce, etc.

Moreover, according to Nuttall (2005) the problem is not that nobody reads FL - Foreign Language - for authentic reasons, but that the students do not. This is a problem of motivation. Thus English teachers have to make various suggestions that may help increase motivation by making FL reading interesting itself and try to give students reading materials that reflect the authentic purposes for why people read. This will help them realize that reading is not just a linguistic exercise but also getting the meaning out of a text for some purpose.

Hasanah, conducted a research on the second year students of SLTP Negri 2 Takalar on the difficulties in reading comprehension in 2002 (cited in Syatriana, 2012), concluded that the factors that cause students' difficulties in reading comprehension are: the difficult reading material, the low frequency in receiving reading 
comprehension homework and English structure by the teacher, and the students rarely memorize English words.

Students need to have a background knowledge of the text, and vocabulary in order to get the content of a text. For that to happen, English teachers should innovate, practice, and discover new functional methods to teach reading comprehension. These new methods definitely have their own advantages and disadvantages. At this time, the writer chooses two methods to compare, ThinkAloud and the Visual Imagery method.

Rankin (1988) confirmed that the interaction between the reader and the writer happens not face-to-face but inside the reader's mind; and to observe the trail of thoughts directly is impossible. In order to do so Think-Aloud requires teachers to read aloud the texts and to speak out their thoughts about what is happening in the text orally. The think-aloud strategy makes students understand the content by connecting feelings to action done by the characters in the text since they share their thoughts about it loudly and not just inside their mind.

Visual Imagery is a way for the readers to comprehend the text by visualizing the text. According to Hibbing (2003, p.761), "some students experience confusion due to lack of understanding of critical features in the setting or spatial relationships between characters or items discussed in the text. We have found out that drawing or quick sketch made by the teacher is a useful tool to create understanding". The teacher, therefore, needs to guide the students thoroughly in creating the image as they read and draw.

In addition to that, think aloud has also been researched in the field of English as a foreign language - EFL. Jafarigohar (2013) evaluated the effects of reciprocal teaching vs. think-aloud on pre-intermediate students in Iran. The results confirmed that think-aloud is better in enhancing reading comprehension ability than reciprocal teaching.

In Indonesia, Sukyadi (2009) tried to investigate the effectiveness of using think-aloud instructional scaffolding in teaching reading to the first year Senior High School students. The findings reveal the experimental group showed better performance on reading comprehension than the control group.

In the same way, there is also a research on visual imagery done by Jenkins (2009). She investigated the effects of mental imagery instruction on using science expository texts on middle school students. The results suggest that mental imagery strategies are beneficial to middle school students when reading science expository texts. She recommended that these strategies could be used as a continuous effort in the classroom rather than only for a short term.

In Indonesia, S. Ratna investigated cognitive reading strategies frequently used among EFL students at STKIP Garut in 2014. The result shows that Visual Imagery were used by more than half of the respondents $(60.5 \%$ and $63.2 \%)$. Ismail (2011) did a research at public senior high school 1 in Ternate, she gave them questionnaire to investigate the students' reading strategies in reading comprehension. The result shows that all high, middle, and low achiever students 
sometimes employed the same strategies in constructing the context, the use of placing new words into context, using imagery, and developing cultural understanding.

Majors (2001) in his literature review, stated that there is a lack of studies in comprehension instruction about teachers' beliefs and use of imagery. The information about the teachers' knowledge and understanding of imagery as a teaching tool is not available at this time.

Based on the background above, in this study, the writer is interested in comparing and investigating the different enhancement of the reading comprehension achievement between the class who were taught with Think-Aloud and Visual Imagery especially in middle school students.

\section{Statement of the problem}

This study aims to compare the significant difference between those who were taught using Jigsaw 1 model and those who were taught using picture composition to enhance the students' ability in writing descriptive text. This study was conducted in order to answer the following question:

Is there any significant difference between those who were taught using Jigsaw 1 model and those who were taught using picture composition to enhance the students' ability in writing descriptive text?

\section{Hypotheses of the study}

The hypothesis in this research are:

Null Hypothesis $\left(\mathrm{H}_{0}\right)$ : There is no significant difference on students' reading comprehension between those who are taught using Think Aloud and those who are taught using Visual Imagery.

Alternative Hypothesis $\left(\mathrm{H}_{\mathrm{a}}\right)$ : There is a significant difference on students' reading comprehension between those who are taught using Think Aloud and those who are taught using Visual Imagery

\section{Scope and limitation of the study}

This study is limited to grade 8E and 8F students of SMPN 1 Parongpong, west Java, Indonesia. The strategies used in this study are Think-Aloud and Visual Imagery. The material used in this study are the students' text book, English in Focus grade 8 .

\section{Review of related literature}




\section{Reading Comprehension}

Burns et al., (2012) stated that reading is a combination of skills, which work together and build on each other, that leads to derive meaning from print to the joy of sharing another person's insights. Reading comprehension has been described by recent theories as the act of relating textual information to existing schemata - the prior knowledge that people develop about things, places, or ideas (Pearson et al., 1979 cited in Burns et al., 2012).

Moreover, reading comprehension is crucial because general knowledge mostly depends on reading. Only wide reading - a significant strategy for students to develop academic background knowledge (Marzano, 2004) - can handle the 'background' or cross-cultural problem (Bright and McGregor, 1973). In addition to that, quantity and quality of reading greatly influence the further education. Quick, efficient and imaginative reading are needed by every important study skill.

A person reads because there is a desire to get something from the writing: facts, ideas, enjoyment, even feelings of family community (from a letter): whatever it was, it is to get the message that the writer had expressed and being interested in what the writing meant (Nuttall, 2005).

\section{Problems in Reading}

Reading is not just simply an active process but an interactive one. It is quite different from conversation since in reading, an author of book is not normally available, which makes the task of the reader difficult in order to decipher and comprehend author's perspectives (Nuttall, 2005).

Reading comprehension is truly crucial in an instructional circumstance where students are required to be competent in English even if they rarely speak the language. As an example, most Indonesian students, who have been studying English for six years, are hardly able to comprehend and use English effectively (Nur, 2004 cited in Sunggingwati, 2013).

The EFL - English as a foreign language - reading is hard to achieve for Indonesian students who are greatly influenced by their cultural background and lack of motivation (Lamb \& Coleman, 2008; Setiono, 2004; Masduqi, 2014). One example about cultural background is the concepts that create different reference in some cultural contexts that leads to varied readers' expectations. Alptekin (2008, cited in Erten, 2009) provided a sample about having breakfast to Turkish and British readers. Turkish readers, for their breakfast, look forward to have cheese, olives, jam, honey, tomatoes, cucumber, and brewed tea (with no milk at all). Meanwhile, British readers look forward to have cereal, toast, butter and jam, honey, and tea (with or without milk) or coffee; or for a cooked breakfast, to have sausages, bacon, baked beans, hash browns, fried eggs, and grilled tomatoes.anford (2015) gave a statement about students' lack of motivation that when having no desire in reading, the only time students read a book is when it is definitely essential, and most of them do not 
read with pleasure. Another reason for secondary students is that for them reading is a cognitive task. Furthermore, when the learner has no interest in the topic, he is hardly focused to learn.

Hasnawati conducted a research on the second year students of SLTP Negri 2, Takalar on the difficulties in reading comprehension in 2002 (cited in Syatriana, 2012), concluded that the factors that cause students' difficulties in reading comprehension are: the reading materials that are hard for them to understand, the low frequency in receiving reading comprehension homework, the teacher's grammar, and the students' low vocabulary.

As Bromley (2007) stated in accordance with students' low vocabulary, "Vocabulary development is both an outcome of comprehension and a precursor to it, with word meanings making up as much as $70-80 \%$ of comprehension" (p. 528).

Lastly, poor working memory affects a student's reading comprehension (Alloway, Gathercole, Kirkwood, \& Elliott, 2009; Swanson, Kehler, \& Jerman, 2009, cited in Sanford 2015). Working memory let a student to store information in shortterm memory while being immersed in doing cognitive tasks. In other words, it help the student to activate prior knowledge about a topic, to use context clues to establish word meaning while remembering what has just been read.

\section{Think Aloud Method}

Think aloud are said to be the inexact reproductions of a person's actual thought; with his own mind's eye, no reader is capable to wholly capture everything. Therefore, think-aloud helps reader in catching glimpses into hidden activity, allowing reader to understand what is happening below the surface of consciousness (Wilhelm, 2006). According to Mockel (2013), think aloud method let participants read aloud a passage from a text sentence by sentence. After each sentence, the student says what he or she is thinking or doing to understand the text. The teacher will use probing questions to encourage responses from the student. Student responses involves evidence in understanding, elaborating, reasoning, analyzing or judging the text. According to Someren et al., (1994);

"Think aloud protocols informs about how learners solve problems, what difficulties they may encounter and to what extent and in what contexts they use certain strategies in a learning task" (p.8).

There have been several studies that shows significant enhancement in reading score on comprehension tests on students who verbalize their reading and thoughts (Oster, 2001). For example, a classic study by Bereiter and Beck (1985, quoted by Duke and Pearson, 2002) found out that students had better comprehension and were better at summarizing information from a text after they were asked to think aloud while reading.

Think aloud helps to comprehend "how human brain works and by analyzing students' behavior, one can discover things about them, so he can reconsider his 
reading habit, his expectations of students and the role of reading comprehension in language teaching" (Jahandar 2012, p.1).

Moreover, As Someren (1994, p.36 cited by Ozek and Civelek, 2006; Richard and Vacca, 2003) notes, when a task is difficult, think-aloud works better. Since all English text is considered difficult by most students, then think aloud might be a way to comprehend a text better.

Jafarigohar (2013) confirmed that think-aloud is better in enhancing reading comprehension ability than reciprocal teaching. Think aloud encourages students in making prediction, guessing unknown words and recognizing main idea.

Furthermore, think aloud help students to be good readers. Farr and Conner (2004) explain what good readers do; based on their background knowledge, they draw, make predictions, visualize events in a text, and acknowledge confusion and a text's structure. Moreover, good readers identify a purpose for reading.

\section{Weakness of Think Aloud}

According to the National Institute for Aviation Research at Wichita State University (2004), these are the disadvantages of Think Aloud protocols: 1). Think aloud slows down the reasoning process that may lead in avoiding mistakes that usually occurred; 2). Think aloud, to some participants, may appear unusual and disturbing for it might be distinct with their learning strategies; 3). To keep sharing and talking the thought for two to three hours is tiring; 4). In order to get the best results, it require a skilled evaluator in this strategy.

\section{Visual Imagery Method}

Good readers construct mental images or visualize the events of a text as they read a text (Farr \& Conner, 2004). Hibbing (2003) asked her students to reflect upon the quote, "A picture is worth a thousand words", the middle school reluctant readers responded with these comments: "A picture helps me by showing what's going on", "In my textbooks when they show pictures it helps me see what they are talking about", "If you look at a picture, it puts more ideas in your head", "If you have a picture it may take a thousand words to get the true meaning of the picture". (p. 758)

When children are able to create visual images about information and stories while listening, the pictures provides the framework for organizing and remembering the information (Gambrell \& Bales, 1987, cited by Mcdonald, 2001). Visual perception involves identification and interpretation of size, shape, and relative position of letters and words (Burns et al, 1984).

Visualization has been famous as the easiest way to elaborate things and as the most difficult to be practiced (Erfani, 2011). For example, read a text aloud, stop at some point, tell students to draw what they are imagining. Moreillon (2007) stated, 
the best way to practice visualization is to have students close their eyes and creating images about the text as they listen to text, and then share their pictures.

Woolley (2010) asserted that, when visual and verbal processes are incorporated, children are much more attracted during reading because they can actively make use of their prior knowledge even more efficiently. Thus, successful readers tend to be imaginative and able to pick and arrange the information from complex texts.

Van Meter, et al. (2006) supported that drawing was a goal-directed activity that enables enhancement in reading comprehension. It is found that learners who made drawings are engaged in self-monitoring behaviors than learners who did not draw. They suggested that when readers draw, an organized selected elements construct a mental model as the learner activates prior knowledge to connect it with the text.

Specifically, pictures helps reading a text become more enjoyable, generates positive attitudes toward reading and toward illustrated text in particular, and influences the time readers are willing to read a text. All these effect are particularly beneficial on reluctant readers (Hibbing 2003).

\section{Weakness of Visual Imagery}

Visual-spatial mental imagery is more beneficial for advanced level readers, to assist reading comprehension at discourse level for visual-spatial mental imagery is more to a physical reality than 2D visual or spoken information. (Knauff \& Johnson Laird, 2002; Ragni et al., 2006; Rapp, 2005; Zwaan \& Madden, 2005; cited in Ashton, 2012).

Allen (2008) stated that some students might have difficulty in creating mental image with a different range of phenomenon. "Many students have weakness in creating mental images resulting in poor reading comprehension, low oral language comprehension, weak verbal skills, and poor critical thinking." (p.29)

\section{METHODOLOGY}

This study is a quantitative study that uses comparative design, test the comprehension of the students through pre-test, treatment, and post-test. The purpose is to see whether Think-Aloud and Visual Imagery have significant difference in enhancing students' reading comprehension ability. 
Table 3.1

Research Design

\begin{tabular}{|c|c|c|c|}
\hline Groups & Pre-test & Treatment & Post-test \\
\hline Think Aloud & $\mathrm{A}$ & $\mathrm{X}_{1}$ & $\mathrm{~A}$ \\
\hline Visual Imagery & $\mathrm{A}$ & $\mathrm{X}_{2}$ & $\mathrm{~A}$ \\
\hline
\end{tabular}

Not

A : Students' reading comprehension scores in pre-test and post-test

$\mathrm{X}_{1} \quad$ : Think-Aloud method

$\mathrm{X}_{2} \quad$ : Visual Imagery method

\section{Participants}

In this study, the population were about 350 students of grade 8 SMPN 1 Parongpong, Bandung. The samples were the students of grade $8 \mathrm{E}$ as the group taught with Think-Aloud method and grade $8 \mathrm{~F}$ as the group taught using Visual Imagery.

\section{Instruments of the Research}

The Instruments of this research were reading comprehension test given as pre-test and post-test. The pre-test was designed to measure the ability of the students in reading comprehension before Think-Aloud and Visual Imagery were applied. The post-test was designed to see the result of the study after Think-Aloud and Visual Imagery were applied. The comprehension test was in the form of multiple choice question with a total number of 35 questions. Pre-test and post-test were originally made by the researcher and adapted from the materials in the text book used by the school in the second semester, English in Focus for grade 8.

\section{Procedures}

The teacher applied Think-Aloud to class $8 \mathrm{E}$ and Visual Imagery to class $8 \mathrm{~F}$. Both classes learned from the same materials from the text book. The teacher promoted the assigned text (e.g. narrative, fable, legend and folklore) and elaborate the purpose of the Think-Aloud and Visual Imagery strategy at first. Furthermore, in visual imagery method, teacher would first define the concept of using images to represent information. 


\begin{tabular}{|c|c|}
\hline $\begin{array}{l}\text { The following are the steps in utilizing } \\
\text { Think-Aloud method: }\end{array}$ & $\begin{array}{l}\text { The following are the steps in utilizing } \\
\text { Visual Imagery method: }\end{array}$ \\
\hline $\begin{array}{l}\text { 1. The teacher read the selected passage } \\
\text { aloud as the students read the same text } \\
\text { silently. }\end{array}$ & 1. The teacher began reading. \\
\hline $\begin{array}{l}\text { 2. At certain points, the teacher stopped } \\
\text { and think aloud the answers to some of } \\
\text { pre-selected questions that can be found } \\
\text { in the text. e.g.: } \\
\text { What is this topic about? } \\
\text { What will I learn from this topic? } \\
\text { Do I understand from what I just read? } \\
\text { Do I have a clear picture in my head } \\
\text { about this information? } \\
\text { What are the important points in this } \\
\text { reading? } \\
\text { What new information did I learn/get? } \\
\text { Does it fit in with what I already know? }\end{array}$ & $\begin{array}{l}\text { 2. The teacher paused after a few } \\
\text { sentences or paragraphs that had a good } \\
\text { descriptive information. }\end{array}$ \\
\hline $\begin{array}{l}\text { 3. After the first session, students did } \\
\text { think-aloud with another topic from the } \\
\text { textbook in small groups; teacher and } \\
\text { other students monitor and help. }\end{array}$ & $\begin{array}{l}\text { 3. The teacher shared the image created } \\
\text { in her mind, and talked about which } \\
\text { words from the book that helped "draw" } \\
\text { the picture. (The picture can be related } \\
\text { to the setting, the characters, or the } \\
\text { actions) }\end{array}$ \\
\hline $\begin{array}{l}\text { 4. The teacher kept track of their } \\
\text { understanding by rereading a sentence, } \\
\text { reading ahead to clarify, and/or looking } \\
\text { for context clues. }\end{array}$ & $\begin{array}{l}\text { 4. Teacher then continue reading. Pause } \\
\text { again and share the new image that's } \\
\text { been created. }\end{array}$ \\
\hline $\begin{array}{l}\text { 5. The teacher gave students questions } \\
\text { regarding the topics to monitor the }\end{array}$ & $\begin{array}{l}\text { 5. Teacher asked the children to share } \\
\text { what they sees, hears, tastes, smells and }\end{array}$ \\
\hline
\end{tabular}




\begin{tabular}{|l|l|}
\hline students' reading comprehension. & $\begin{array}{l}\text { feels, to show what words helped them } \\
\text { to picture the mental image and } \\
\text { emotions. }\end{array}$ \\
\hline & $\begin{array}{l}\text { 6. The teacher and students discussed } \\
\text { about their pictures and the background } \\
\text { knowledge they had about the story. }\end{array}$ \\
\hline $\begin{array}{l}\text { 7. After the first session, teacher } \\
\text { separated the students into small groups } \\
\text { randomly. }\end{array}$ \\
\hline $\begin{array}{l}\text { 8. The students read another topic from } \\
\text { the textbook, and begin to create their } \\
\text { own visual imagery in a group with } \\
\text { teacher's guidance and other students' } \\
\text { monitor. }\end{array}$ \\
\hline $\begin{array}{l}\text { 9. The teacher gave students questions } \\
\text { regarding the topics to monitor the } \\
\text { students' reading comprehension. }\end{array}$ \\
\hline
\end{tabular}

\section{RESULTS AND DISCUSSION}

In processing the data, the researcher used statistical program, SPSS 17.

Table 4.1

Result of Pre-test, Post-test, Standard Deviation, and Gain

\begin{tabular}{|c|c|c|c|c|}
\hline \multirow{2}{*}{} & \multicolumn{2}{|c|}{ Visual Imagery } & \multicolumn{2}{c|}{ Think Aloud } \\
\cline { 2 - 5 } & Mean & St. Deviation & Mean & St. Deviation \\
\hline Pre - test & 59.1562 & 17.9158 & 49.2759 & 10.271 \\
\hline Post - test & 62.375 & 21.1367 & 55.8621 & 15.1604 \\
\hline Gain & 0.03888 & 0.453 & 0.1253 & 0.24115 \\
\hline
\end{tabular}

Through the descriptive statistics done by SPSS, it can be seen that the reading comprehension between students who are taught with Think Aloud method and who are taught with Visual Imagery method both are enhanced even though not 
significantly. The average gain for Visual Imagery group is 0.0388 and Think Aloud group is 0.1253 .

\section{Discussion of the Research Finding}

There are uncontrollable factors on why both Visual Imagery group and Think Aloud group had only little enhancement, such as lack of vocabulary and background knowledge that leads to lack of interest. In other words, the sample of both groups, are in beginner levels. As Burt, Peyton and Schaetzel (2008: 2) stated; Low-literate learners "find letters and any graphical representations - maps, graphs, charts, even pictures - difficult to interpret".

Kweldju (1996, cited in Cahyono 2006) discovered that even English department students were not interested in reading textbooks, despite of having admitted that it were useful. She stated that the reasons are the students' limited background knowledge, students' incapacity in comprehending the content, and the text's complicated grammar. Even college students found it hard to understand English textbooks. On the other hand, when students - middle schools in Indonesia did not understand what the words mean, then they could not picture it out in his mind.

Moreover, they're unconfident with their knowledge and ability. When students were asked to draw the picture that came out in their minds, they got embarrassed and weren't being confident about the image being suitable with what it actually means. But when they finally had the meaning of the words, they were reluctant to draw it properly and exactly on the paper. According to Bell (1986, cited in Allen, 2008), "these symptoms of weak imagery result in poor reading comprehension which include rereading material numerous times to understand it, difficulty bringing words together to form mental imagery, difficulty understanding cause-effect, may not grasp main idea or inferences from spoken or written language, asking and re-asking questions that have been answered, poor logical thinking and problem solving and showing difficulty expressing themselves easily and fluently." (p.29)

Cain et al., (2001) observed that poor readers' comprehension abilities tended to be less successful in keeping track of irrelative information disruption, which leads to creating inexact mental models.

Since the average gain for both Think Aloud and Visual Imagery group was not significantly different, it can be concluded that Think Aloud and Visual Imagery method is not really helpful for beginner students. McKeown and Gentilucci (2007) conducted a small study of 27 middle school English Language Learners (ELL) with different reading proficiency levels, early intermediate, intermediate and early advanced, the study shows that the think-aloud strategy interfered comprehension for more advanced students and doesn't benefit the beginning ELL reader.

Regardless of these two methods did not enhance student's reading comprehension ability significantly, it can be concluded that Think Aloud method gives more benefits than Visual Imagery method for the 46 samples in both groups. 
Since the average gain for Think Aloud group is larger than the average gain for Visual Imagery group.

\section{CONCLUSION}

Think Aloud method and Visual Imagery method enhance students' reading comprehension ability insignificantly and there is no significant difference between the gain scores. Even so, it is still crucial to try it to another level of students and to conduct a study about Think Aloud and Visual Imagery in order to find out the best level, situation, and procedures that best fit in with the method.

\section{REFERENCES}

Allen, L. Jennifer. 2008. The Impact of Speech-language Pathologist Service Delivery Models for Concept Imagery Formation Instruction on Second Grade Students' Language Achievement Outcomes. University of Nebraska at Omaha. Department of Educational Administration and Supervision. Published by: ProQuest. ISBN: 0549884653, 9780549884651.

Anne Nielsen Hibbing \& Joan L Rankin-Ericson 2003. A picture is worth a thousand words: Using visual images to improve comprehension for middle school struggling readers. The Reading Teacher, Vol. 56, No. 8 (May, 2003), pp. 758-770Published by: International Reading Association Stable URL: http://www.jstor.org/stable/20205292

Ashton, A. Aleksandra. 2012. Mental Imagery and Reading Comprehension Proficiency in English Second Language Learners: An Exploratory Study. University of the Witwatersrand, Johannesburg.

Braunger, J., \& Lewis, J.P. (2006). Building a Knowledge Base in Reading (Second Edition). USA: IRA \& NCTE 124-129, 140-146.

Bromley, K. (2007). Nine things every teacher should know about words and vocabulary instruction. Journal of Adolescent \& Adult Literacy, 50, 528536.

Burns, Paul C., Sandy H. Smith, and Betty D. Roe. Teaching Reading in Today's Elementary Schools. 11th ed. Belmont, CA: Wadsworth Cengage Learning,

2012. 8. Print.

Burt, M., J. K. Peyton \& C. Van Duzer 2005. How should adult ESL reading instruction differ from ABE reading instruction? [Retrieved April 4, 2016] CAELA Network Brief, March. Available at http://www.cal.org/caela/esl_resources/briefs/Readingdif.pdf

Cain, K., Oakhill, J. V., Barnes, M. A., \& Bryant, P. E. (2001). Comprehension skill, inference making ability, and the relation to knowledge. Memory and Cognition, 29, 850- 859. doi: 10.3758/BF03196414 
Cain, K., Oakhill, J., \& Bryant, P. E. (2004). Children's reading comprehension ability: Concurrent prediction by working memory, verbal ability, and

component skills. Journal of Educational Psychology, 96, 31-42. doi:10.1037/0022- 0663.96.1.3

Cahyono, Bambang Yudi., Widiati Utami. "THE TEACHING OF EFL READING IN THE INDONESIAN CONTEXT: THE STATE OF THE ART" (2006). Universitas Negeri Malang.

Duke, Nell K. \& P. David Pearson. (2002). Effective strategies for developing reading comprehension (pp.205-215).

Erten, İsmail Hakkı \& Razı, Salim. (2009). The effects of cultural familiarity on readingcomprehension. Çanakkale Onsekiz Mart University Turkey. Reading in a Foreign Language. April 2009, Volume 21, No. 1 ISSN 1539-0578 pp. 60-77.

Farr, Roger and Jenny Conner. 2004. "Using Think-Alouds to Improve Reading Comprehension." Accessed December 2, 2015. http://www.readingrockets.org/article/102/

Ismail, Ade (2011) AN INVESTIGATION OF STUDENTS' STRATEGIES IN COMPREHENDING ENGLISH READING MATERIALS: A case study at one Senior High School in Ternate. S2 thesis, Universitas Pendidikan Indonesia.

J. A. Bright, G. P. McGregor. Teaching English as a Second Language. Great Britain: Lowe \& Brydone (Printers) Ltd., Thetford, Norfolk. 1973.

Jafarigohar, Manoochehr., et al. "The Effects of Reciprocal Teaching vs. ThinkAloud on Reading Comprehension of Pre-Intermediate Students in Iran" (2013).

Jahandar, Shahrokh., et al. "The Think Aloud Method in EFL Reading Comprehension" (2012).

Majors, M. Sandra. (2001). REPORTED USE OF IMAGERY STRATEGY IN READING COMPREHENSION INSTRUCTION. Oklahoma State University Stillwater, Oklahoma.

Marzano, R. (2004). Building Background Knowledge for Academic Achievement. Alexandria, VA: ASCD

Masduqi, Harits. "Efl Reading in Indonesian Universities: Perspectives and Challenges in Cultural Contexts" (2014).

Mcdonald, Shannon. "Experiences and Pictures: Using Visual Imagery and Background Knowledge to Improve Reading Comprehension" (2001).

McKeown, Regina \& Gentilucci, James. Think-Aloud Strategy: Metacognitive development and monitoring comprehension in the middle school secondlanguage classroom". Journal of Adolescent \& Adult Literacy, October 2007, Volume 51, Number 2, pp.136-147.

Milenovic, M. Zivorad. (2011). APPLICATION OF MANN-WHITNEY U TEST IN RESEARCH OF PROFESSIONAL TRAINING OF PRIMARY 
SCHOOL TEACHERS. Metodicki obzori 6 (2011)1. Original scientific article. UDK: 159.9.072:371.13. Received: 18. 8. 2010.

Mockel, L. Joan, "Thinking Aloud in the Science Classroom: Can a literacy strategy increase student learning in science?" (2013). Dissertations and Theses. Paper 1420.

Moreillon, (2007). Collaborative Strategies for Teaching Reading Comprehension:

Maximize Your Impact. American library Association, Chicago.

Nuttall, Christine. (2005). Teaching Reading Skills in a Foreign Language. Oxford, UK: Macmillan Education.

Pearson, P. David, et al. The effect of background knowledge on Young children comprehension of explicit and implicit information. Urbana: University of Illinois, Center for the study reading, 1979.

S. Ratna, Anne. (2014). The Use of Cognitive Reading Strategies to Enhance EFL Students' Reading Comprehension. International Journal of Education (IJE), Vol. 2, No. 1.

"Think-Aloud Protocol." Evaluation Toolbox for Aviation Technical Writers. National Institute for Aviation Research, 11 May 2004. Web. 9 May 2016.

$<$ https://www.niar.wichita.edu/humanfactors/toolbox/T_A\%20Protocol.htm>.

Rankin, J. M. (1988). Designing thinking-aloud studies in ESL reading. Reading in a Foreign Language, 4.

Riswanto, et al. (2014). The Effect of Using KWL (Know, Want, Learned) Strategy on EFL Students' Reading Comprehension Achievement. International Journal of Humanities and Social Science Vol. 4, No. 7(1).

Rizqiya, S. Rissa. "The Use of Mind Mapping In Teaching Reading Comprehension" (2012).

Sanford, Karen L., "Factors that Affect the Reading Comprehension of Secondary Students with Disabilities" (2015). Doctoral Dissertations. Paper 125.

Sukyadi, Didi., \& Hasanah, E. U.. 'Scaffolding Students' Reading Comprehension with Think-Aloud Strategy". (2009).

Sunggingwati, Dyah \& Hoa Thi Mai Nguyen. "Teachers' Questioning in Reading Lessons: A Case Study in Indonesia" (2013).

Syatriana, Erny. "Developing the Students Reading Comprehension through Cognitive Reading Strategies of the First Year Students of SMAN 16 Makasar" (2012).

Shapiro, S. S. and Wilk, M. B. (1965). "An analysis of variance test for normality (complete samples)", Biometrika, 52, 3 and 4, pages 591-611.

Stable URL: http://www.jstor.org/stable/2333709

Someren, Maarten W. Van, Yvonne F. Barnard \& Jacobijn A.C. Sandberg. (1994). The think aloud method: A practical guide to modelling cognitive processes. London: Academic Press.

Uyanto, Stanislaus S. 2009. Pedoman Analisis Data dengan SPSS. Graha Ilmu. Yogyakarta. Sugiono. 2008. Metode Penelitian Bisnis. AlfaBeta. Bandung. 
Van Meter, P., Aleksic, M., Schwartz, A., \& Garner, J. (2006). Learner-generated drawing as a strategy for learning from content area text. Contemporary Educational Psychology.

Wiener, Harvey S., and Charles Bazerman. Reading Skills Handbook. 9th ed. New York: Pearson Education, 2006.

Wilhelm, Jeffrey D. (2006). Improving comprehension with think-aloud strategies: A study guide for. Scholastic Publications. Think Aloud Strategy. 